Annals of Glaciology $3 \quad 1982$

(C) International Glaciological Society

\title{
THIRD INTERNATIONAL SYMPOSIUM ON
}

\section{ANTARCTIC GLACIOLOGY:}

\section{OPENING ADDRESS}

by

\author{
Dr Edward P. Todd
}

Director, Division of Polar Programs, National Science Foundation

It is a pleasure to join President Jennings in welcoming you to the third International symposium on Antarctic Glaciology (TISAG). On behalf of the United States Antarctic Research Program and the National Science Foundation, I extend greetings and our best wishes for a successful meeting.

You scientists in attendance here are indeed an unusual group. You represent many countries, yet many of you have been close personal and professional colleagues for many years. You have been brought together by a comnitment to the study of glaciology; an extremely exciting area of research which represents the union of many scientific specialties. The results of your research in years past have had a dual importance both for the scientific results themselves and also for their political impact.

The work of the international glaciological community, together with that of your colleagues in the other polar sciences, reaching a peak during the International Geophysical Year and continuing to the present, has been a major factor in bringing the nations together to formulate the Antarctic Treaty and in using that treaty as a peaceful mechanism for determining the future of a continent. This is probably the only instance wherein international cooperation in science provided the impetus and the rationale for a major treaty among nations. The Antarctic Treaty has been working, and working well, for the past twenty years.

At the present time, many feel the treaty to be under great stress because of worldwide concern over two major resource issues. These are issues of how to manage marine living resources and mineral resources. With respect to the first of these, we have seen the treaty nations develop and sign the Convention for the Conservation of Antarctic Marine Living Resources. Probably, by the end of this year, enough nations will have ratified the convention for it to enter into force. Additionally, just a few weeks ago at the eleventh Consultative Meeting in Buenos Aires, the treaty nations agreed to proceed expeditiously in the attempt to develop a similar agreement to govern the exploitation of nineral resources if economically useful deposits are ever discovered. Politically it is expected that the minerals issue will be quite a bit inore difficult for the treaty nations to solve than was the marine living resources issue.

It is hard, at this time, to develop a good feeling for whether or not Antarctic mineral resources will ever be of importance to the world's economy. However, I am sure many of you will share with me the feeling that, in the long run, the export from Antarctica which will be of the most importance to human society will be the results of the scientific research done there. I would remind you that essentially all the research done there, in whatever discipline, relates to one or another aspect of the environment. The Antarctic continent plays a major role in governing the operation of the major global environment systems: the atmosphere, the oceans, and, of supreme interest to this group, the cryosphere. I cannot help but feel that the improvement of our detailed understanding of how these systems work, and our ability to predict their changes, is the greatest contribution we, as scientists, can make to the longrange welfare of the human race.

This symposium is an important step in the long process of carrying out that task. It is bringing you together to report the results of your research as an instalment to Antarctica's export balance of trade. The work derives from many scientific disciplines. Much is the result of individual projects but a gratifying fraction of what is to be reported derives from true internationally cooperative endeavors.

It is quite appropriate that the third International Symposium on Antarctic Glaciology be held here at The Ohio State University for the scientists at the Institute of Polar Studies have not only made this university known in polar science circles but they have often been at the center of cooperative projects with scientists of other nations. When Professor Goldthwait started the institute about twenty-one years ago he may or may not have had in mind something quite close to what has evolved; nevertheless, I believe he has good reason to be pleased with the institute and with the fact that OSU and the institute are playing host to the TISAG. A week or so ago, the university honored Emeritus Professor Goldthwait by awarding him its distinguished service medal. I hope that this symposium will further honor him and the institute with the beauty of your results and the vigor of your discussions. 
https://doi.org/10.3189/S0260305500002421 Published online by Cambridge University Press 